\title{
Impact Assessment of Tribal Sub Plan (TSP) Project on Socio-economic Status of Tribal of Tinsukia District, Assam, India
}

\author{
Sikha Deka $^{1 *}$, Mukesh Sehgal ${ }^{2}$, M. Idris ${ }^{2}$ and A.C. Barbora ${ }^{1}$
}

${ }^{1}$ Citrus Research Station, Assam Agricultural University, Tinsukia, Assam, India

${ }^{2}$ ICAR-National Research Centre for Integrated Pest Management, New Delhi, India

*Corresponding author

\section{Keywords}

Impact Assessment,

Socio-economic

Status, Tribal Sub

Plan, Assam

Article Info

Accepted:

12 March 2019

Available Online:

10 April 2019

\section{A B S T R A C T}

The present study was conducted in Kakopather and Marghertia blocks of Tinsukia district of Assam. With the interventions of the Tribal Sub Plan (TSP) project during the past 3 years i.e. 2015-16, 2016-17 and 2017-18, a perceptible improvement in the crop productivity has been observed. With the focussed programmes and introduction of new technologies, the way of farming is transforming from subsistence low-input low-output production system to commercialization. Significant difference was found in food security, habitat security, occupational security, educational security and social security in before and after implementation of TSP.

\section{Introduction}

Tinsukia is one of the most important city of Assam, located in upper Assam area. The population of the Tinsukia district is $1,327,929$ with 268598 households. The literacy rate of the district is 70.92 per cent ${ }^{1}$. The livelihood of the people-based tea plantation and agriculture such as orange, lemon, ginger, paddy and people are also working in coal mines and oil fields. Fifteen numbers of tribes are reported from Assam ${ }^{2}$. The major tribal communities of Tinsukia district are Ahoms, Sutiya, Moran, Muttock, Singpho, Nepali etc. including minor tribes like Tai Phake, Khamyang, Nocte etc. Being a basic human being, most of the tribal communities are residing in the isolation i.e. away from the urban area (advance social groups), particularly in forest areas where limited resources of development are available. Tribal are extremely poor, no understanding of society, very sigh and hesitate to intermingle with other advance society like urban and rural $^{3}$. These are the well-known characteristics of tribal communities. Tribal are socio- economically very backward as compared to general population, even schedule caste and other back ward classes ${ }^{4}$. No Primitive Tribal Groups (PTGs) are found in Assam². 
A study was conducted in Kakopather and Marghertia blocks of Tinsukia district, Assam and collected baseline information by personally interviewing randomly selected 800 farmers from thirty villages of two blocks during 2015-16 and 2016-17 under aegis of ICAR-NCIPM-TSP project in collaboration with Citrus Research Station (CRS), Assam Agricultural University (AAU), Assam ${ }^{5}$. The study revealed that the farmers were very poor with low literacy and growing only rice, tea, ginger and oranges without any awareness of advance agricultural management practise resultant poor yield and less benefit. In the present communication, the impact of the different extension activities like training, demonstration of advance agricultural practices, Front Line Demonstration (FLD) of Integrated Pest Management (IPM) module on tribal farmers field etc., were carried out in the specified area to improve the livelihoods of tribal is being presented.

\section{Materials and Methods}

Under Tribal sub Plan (TSP) project 5 villages from two blocks i.e. i) Kakopather block: Hahkhati, Moderkhat and Dumsi Hatigarh (ii) Marghertia block: Ketetong and Khamanpather were selected in the Tinsukia district, Assam. In these targeted villages, the baseline information like family structure, education, available facilities, land holdings etc. was collected.

Thereafter, extension activities like training and demonstration on advance agricultural practices and group discussions were conducted in selected villages of two blocks. The critical inputs like seeds/seedlings of high yielding varieties of Citrus, paddy, ginger and vegetables and bio-product/agro-chemicals were provided for improving production and protection the crops from diseases and insect pests.
To address the gaps in scientific production technology including rationale of agrochemicals and Integrated Pest Management (IPM), Front Line Demonstration (FLD) on technology development by CRS, AAU, Tinsukia and ICAR- NCIPM, New Delhi were also demonstrated extensively in the selected villages particularly on Assam lemon, Khasi mandarin and ginger. The orange growers were also given training on rejuvenation practices developed by CRS, AAU, Tinsukia. The exposure visits were planned as a starting activity under TSP with an objective of exposing the tribal farmers to the advance technologies and improved practices of farming.

\section{Results and Discussion}

In the previous study, it is revealed that the tribal of Tinsukia district of Assam are socioeconomically backward as compared to the non -tribal and their primary source of livelihood is agriculture ${ }^{5}$. Therefore, it will be pertinent to improve their agricultural practices by dissemination of scientific production technologies through organising training programmes, farmer's day, Front Line Demonstrations (FLDs), group discussions with providing critical inputs like high yielding varieties and chemicals etc. The following measures were taken to enhance their income and simultaneously to ensure sustainable livelihood:

\section{Training programmes}

During 2015-16, 2016-17 and 2017-18, training programmes were organised by ICAR-NCIPM, New Delhi with active collaboration of CRS, AAU, Tinsukia at 7 places and more than 650 tribal farmers were participated in the training programmes (Table 1). Advance scientific technologies particularly on IPM in Khasi mandarin and Assam lemon and production technologies on 
Citrus and ginger were disseminated to the tribal of the specified areas (Fig. 1).

At initiation of TSP project, Assam lemon growers were disorganised, therefore, the middle men were taking advantage and exploited the producers by offering unremunerated prices. Hence, all the Assam lemon growers were organised into a cooperative society and registered the society in the name of "CRS- Naa Dihing Nemu Tenga Unnayan Samity" with a registration number 26210304/1645 dated 26.07.2017. Under the aegis of the society, Assam lemon growers were made aware for collective bargaining for selling of their produce to the middlemen, wholesalers and retailers. As result of collective bargaining for selling of their produce to the middlemen, wholesalers and retailers; the price realization increases manifolds and their income has become almost double.

Extensive training and demonstrations were conducted on rapid propagation methods and nursery management of Assam lemon. Assam lemon nursery was developed at village Hahkhati of Tinsukia district of Assam. Under the aegis of the 'CRS-Naa Dihing Nemu Tenga Unnayan Samity', Assam lemon Nursery has been developed at commercial level. Assam lemon planting materials are being supplied to the farmers of different areas on regular basis. Development of Assam lemon society, not only farmers of area are getting good planting material of Assam lemon but on other side the farmers those are associated with propagation of planting materials are earning good income and also enjoying having a sustainable livelihood.

\section{Organisation of farmers day/ agri- horti show}

Under TSP project, ICAR-NCIPM, CRS, Tinsukia \& Department of Horticulture jointly organised "Farmers day" and "Agri-Horti
Show". In these two extension activities, demonstrations of various technologies of IPM were carried out particularly on Khasi Mandarin. Seedlings of Khasi Mandarin and Assam lemon were also distributed to the farmers. The farmers were urged to adopt IPM and scientific methods of cultivation. More emphasis was given on value addition of the Khasi Mandarin fruits. The products made out of oranges include jam, orange juice, orange peel which is used by gardeners as a slung repellent, orange leaves which can be boiled to make beverage. The orange growers also interacted with the scientists of NCIPM and CRS and learnt the techniques about sustainable management of pest and diseases and systemized orchard management.

\section{Participatory Rural Appraisal (PRA)} Exercises

The income of traditional orange growers dropped drastically to unsustainable level because of insect pests and diseases like trunk borer (Anoplophora versteegi), bark eating caterpillar (Inderbela quadrinotata), lemon butterfly (Papilio spp.), psylla (Diaphorina citri), fruit fly (Dacus dorsalis), twig blight and Phytophthora foot rot respectively ${ }^{6}$. Moreover, planting materials used by the tribal were neither high yielding nor disease and pests resistant. These factors were root cause of declining of the orchards in the areas came into light through Participatory Rural Appraisal (PRA) exercises. To overcome these problems, rejuvenation package was developed with existing technology from ICAR-NCIPM and CRS. This package was demonstrated by organising various off campus training programmes. The responses of farmers in these training programmes were overwhelming. Looking into the positive results of rejuvenation package, the farmers having decline trend in their orchards of adjoining areas also adopted the technology. 
Resultant the production of oranges increased manifold. In spite of good yield, the farmers could not get remunerative price for their produce as the middle men were exploiting them. Since, the income of orange orchards was realized at the end of year during November and December. Due to meet the household expenses, the farmers were compelled to sell their orchards to the middle men at the time of fruit setting stage i.e. in March - April at throw away price. To overcome these problems, the technology of mixed cropping of tea with orange were developed by CRS, AAU, Tinsukia and introduced in these rejuvenated orchards; so that farmers could get a regular weekly income from the green leaves harvested every week. This technology enabled to stop the distressed farmers to sale their orchards in advance to the middle men. Moreover, to discourage the middlemen interferences further, with help of NCIPM and CRS, AAU, Tinsukia several Self-Help Groups (SHGs) were organised in these locations involving unemployed youths to sale their produce in local market. With intervention of NCIPM and CRS, AAU, the income of farmers increased manifolds resultant their livelihood is also improved.

Another PRA exercise was conducted in a tribal dominated area at Moderkhat, district Tinsukia, Assam where most of the framers were doing traditionally shifting cultivation of ginger with poor yield. Majority of the people of this area were poor i.e. residing below poverty line with very low income. The major problems faced by the people of the area as indicated by PRA exercise were use of old planting materials, prevailing of rhizome rot diseases, lack of awareness of scientific production of ginger and exploitation of middlemen. Keeping in view these problems, NCIPM and CRS, AAU, intervened and organised several training programmes and group discussions with the farmers and disseminated the advance technology in the production of ginger such as use of bio-pesticides and bio-fungicides against rhizome rot and other diseases, scientific method of planting and aftercare processing of ginger and low-cost storage structures using locally available materials etc. These technologies were quickly adopted by the famers of locality and enabling them to harvest good crop and start obtaining remunerative price and also avoid distress sale of ginger resultant improved their livelihood.

\section{Front line demonstration}

Front Line Demonstration was carried out at Moderkhat village of Tinsukia district under TSP on best IPM module ${ }^{6}$ for management of insect pests and diseases and to minimize the use of chemicals in Khasi mandarin, Assam lemon and ginger crops (Fig. 2).

During 2015-16, 2016-17 and 2017-18, FLD programmes were demonstrated in 25 acres land of 34 tribal farmers on Khasi mandarin, 26 acres of 38 farmers on Assam lemon and 23 acres of 31 farmers on ginger crop respectively (Table 2).

Insect pest and diseases are causing cognizable damage to the Khasi mandarin (Citrus retticulata), Assam lemon ( $C$. grandis) and ginger (Zingiber officinale) from nursery to harvesting stages. Therefore, IPM strategies were demonstrated at tribal farmer's field to manage the pest and diseases. Data revealed that IPM module recorded higher percentage of increased yield in khasi mandarin (53.34 \%), and Assam lemon $(86.89 \%)$ as compared to conventional method. However, in ginger crop, it is recorded almost double $(94.87 \%)$ then conventional method (Table 3 ). The data of Table 3 also indicated that the activities of natural enemies like natural predators and 
parasitoids were enhanced in IPM module as compared to conventional practices. Due to bio-intensive and minimum use of pesticides in IPM practices, a congenial environment developed in the cropping system for augmentation of the natural enemies ${ }^{6}$. It has already been proved that IPM module was found most effective, economical with less pest's infestation and higher marketable yield 6, 7. Thus, IPM strategy is economically benefitted to the farmers due to sustainable crop protection from pest and diseases with increased productivity and minimum risk or hazard to the human health and environment.

Table.1 Training conducted under TSP Project

\begin{tabular}{|c|c|c|c|c|c|c|}
\hline \multirow[t]{2}{*}{ Title of Training } & \multicolumn{2}{|l|}{ 2015-16 } & \multicolumn{2}{|l|}{ 2016-17 } & \multicolumn{2}{|l|}{$2017-18$} \\
\hline & Place & $\begin{array}{l}\text { Participants } \\
\text { (No.) }\end{array}$ & Place & $\begin{array}{l}\text { Participants } \\
\text { (No.) }\end{array}$ & Place & $\begin{array}{l}\text { Participants } \\
\text { (No.) }\end{array}$ \\
\hline $\begin{array}{l}\text { IPM of Khasi } \\
\text { mandarin }\end{array}$ & Ketetong & 67 & KhamanPather & 70 & - & - \\
\hline $\begin{array}{l}\text { IPM of Assam } \\
\text { lemon }\end{array}$ & - & - & Moderkhat & 76 & Hahkhati & 80 \\
\hline $\begin{array}{l}\text { Production } \\
\text { technologies of } \\
\text { Citrus }\end{array}$ & Nakongpather & 65 & $\begin{array}{l}\text { Dumshi } \\
\text { Hatigarh }\end{array}$ & 58 & Ketetong & 57 \\
\hline $\begin{array}{l}\text { Production } \\
\text { technologies of } \\
\text { Ginger }\end{array}$ & Borgaon & 83 & Hahkhati & 49 & Moderkhat & 73 \\
\hline
\end{tabular}

Table.2 List of beneficiaries of IPM module demonstrations

\begin{tabular}{|l|l|l|l|l|l|l|}
\hline \multirow{2}{*}{ Crops } & $\mathbf{2 0 1 5 - 1 6}$ & $\mathbf{2 0 1 6 - 1 7}$ & $\mathbf{2 0 1 7 - 1 8}$ & \\
\cline { 2 - 7 } & $\begin{array}{l}\text { Area } \\
\text { (acre) }\end{array}$ & $\begin{array}{l}\text { Beneficiaries } \\
\text { (No.) }\end{array}$ & $\begin{array}{l}\text { Area } \\
\text { (acre) }\end{array}$ & $\begin{array}{l}\text { Beneficiaries } \\
\text { (No.) }\end{array}$ & $\begin{array}{l}\text { Area } \\
\text { (acre) }\end{array}$ & $\begin{array}{l}\text { Beneficiaries } \\
\text { (No.) }\end{array}$ \\
\hline Khasi mandarin & 12 & 15 & 3 & 6 & 10 & 13 \\
\hline Assam lemon & - & - & 12 & 18 & 14 & 20 \\
\hline Ginger & 12 & 16 & 11 & 15 & - & - \\
\hline
\end{tabular}

Table.3 Impact of IPM module on different crops after FLD conducted under TSP project

\begin{tabular}{|l|l|l|l|c|c|c|}
\hline Crops & $\begin{array}{c}\text { \% increase in } \\
\text { yield over } \\
\text { Conventional } \\
\text { method }\end{array}$ & \multicolumn{2}{|l|}{ B:C ratio } & \multicolumn{2}{|c|}{$\begin{array}{c}\text { activity of natural enemies in crop } \\
\text { ecosystem }\end{array}$} & $\begin{array}{c}\text { Opinion of farmers } \\
\text { about impact of IPM } \\
\text { practices }\end{array}$ \\
\cline { 3 - 7 } & & Conventional & $\begin{array}{c}\text { IPM } \\
\text { module }\end{array}$ & $\begin{array}{c}\text { \% increase of } \\
\text { parasitisation } \\
\text { over } \\
\text { Conventional }\end{array}$ & $\begin{array}{c}\text { \% increase of } \\
\text { predators visit } \\
\text { over }\end{array}$ & Conventional \\
\hline $\begin{array}{l}\text { Khasi } \\
\text { mandarin }\end{array}$ & 53.35 & 2.30 & 3.10 & 60.45 & 30.30 & positive \\
\hline $\begin{array}{l}\text { Assam } \\
\text { lemon }\end{array}$ & 86.89 & 2.10 & 3.95 & 45.80 & 25.68 & positive \\
\hline Ginger & 94.87 & 3.10 & 5.95 & 30.24 & 34.60 & positive \\
\hline
\end{tabular}


Table.4 Details of places visited and technologies shown to the tribal farmers during exposure visits conducted during last three years

\begin{tabular}{|c|c|c|}
\hline Places visited & Technologies seen / Knowledge gained & $\begin{array}{l}\text { Number of } \\
\text { Beneficiaries }\end{array}$ \\
\hline KVK, Tinsukia & $\begin{array}{l}\text { KVK farm, demonstration plots of } \\
\text { vegetables, horticulture nursery, bio- } \\
\text { fertilizer and bio-pesticides production unit, } \\
\text { poly house, vermicomposting unit etc }\end{array}$ & 85 \\
\hline $\begin{array}{l}\text { KVK, } \\
\text { Dibrugarh }\end{array}$ & $\begin{array}{l}\text { Micro-irrigation systems: Inline/online } \\
\text { drip, sprinkler Farm equipment / } \\
\text { implements: seed planter } \\
\text { Technical guidance: Lecture on improved } \\
\text { rice cultivation }\end{array}$ & 12 \\
\hline $\begin{array}{l}\text { Assam } \\
\text { Agricultural } \\
\text { University, } \\
\text { Jorhat }\end{array}$ & $\begin{array}{l}\text { Fruit orchards: Sapota, mango, } \\
\text { pomegranate, sweet orange, guava, ber, } \\
\text { aonla, etc. } \\
\text { Vegetables demonstration plots: Brinjal, } \\
\text { French bean, tomato, potato, etc. }\end{array}$ & 15 \\
\hline $\begin{array}{l}\text { Citrus } \\
\text { Research } \\
\text { Station, AAU, } \\
\text { Tinsukia }\end{array}$ & $\begin{array}{l}\text { Discussion with scientist on various issues } \\
\text { related to modern agricultural practices and } \\
\text { organic farming, Citrus Nursery, } \\
\text { vermicomposting unit, }\end{array}$ & 85 \\
\hline
\end{tabular}

Fig.1 A- Three day long Training programme at CRS, AAU, Tinsukia; B,C,D- Off- Campus Training programme held at specified areas of Nakong pather, Simanta Tengapani and Hahkhati, respectively
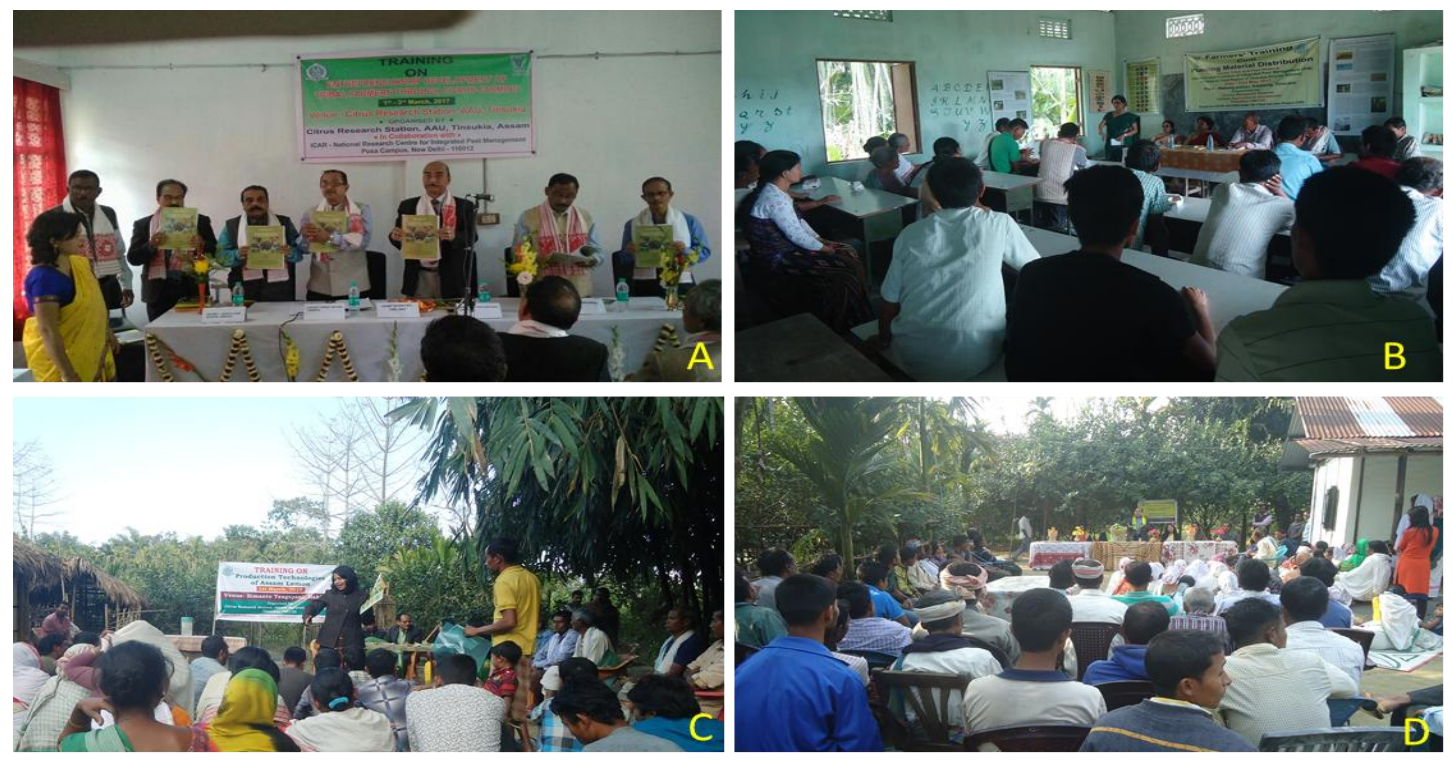
Fig.2 A- Farmers Scientist Interaction; B, C, D- FLDs conducted at specified area
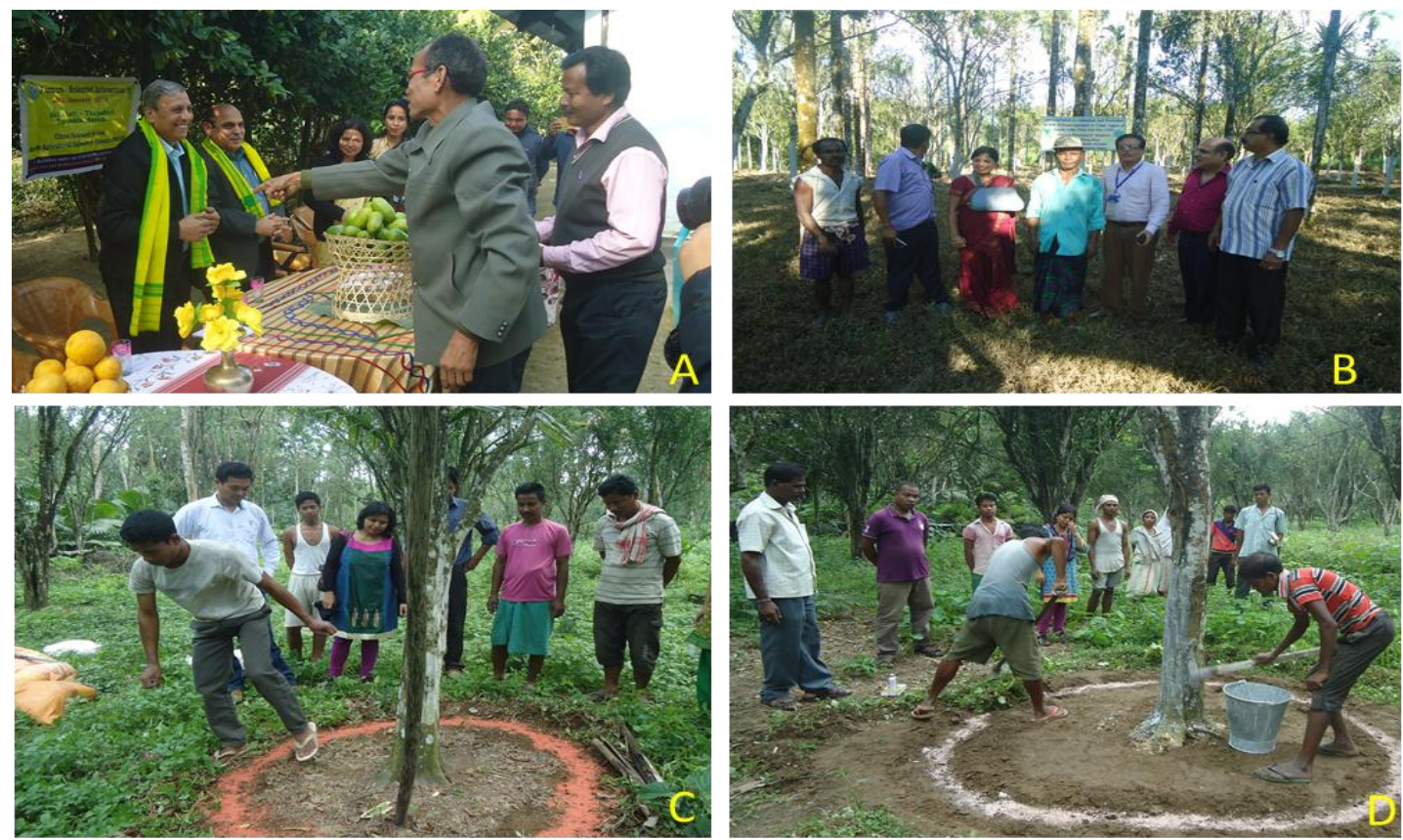

Fig.3 Overall impact of the project

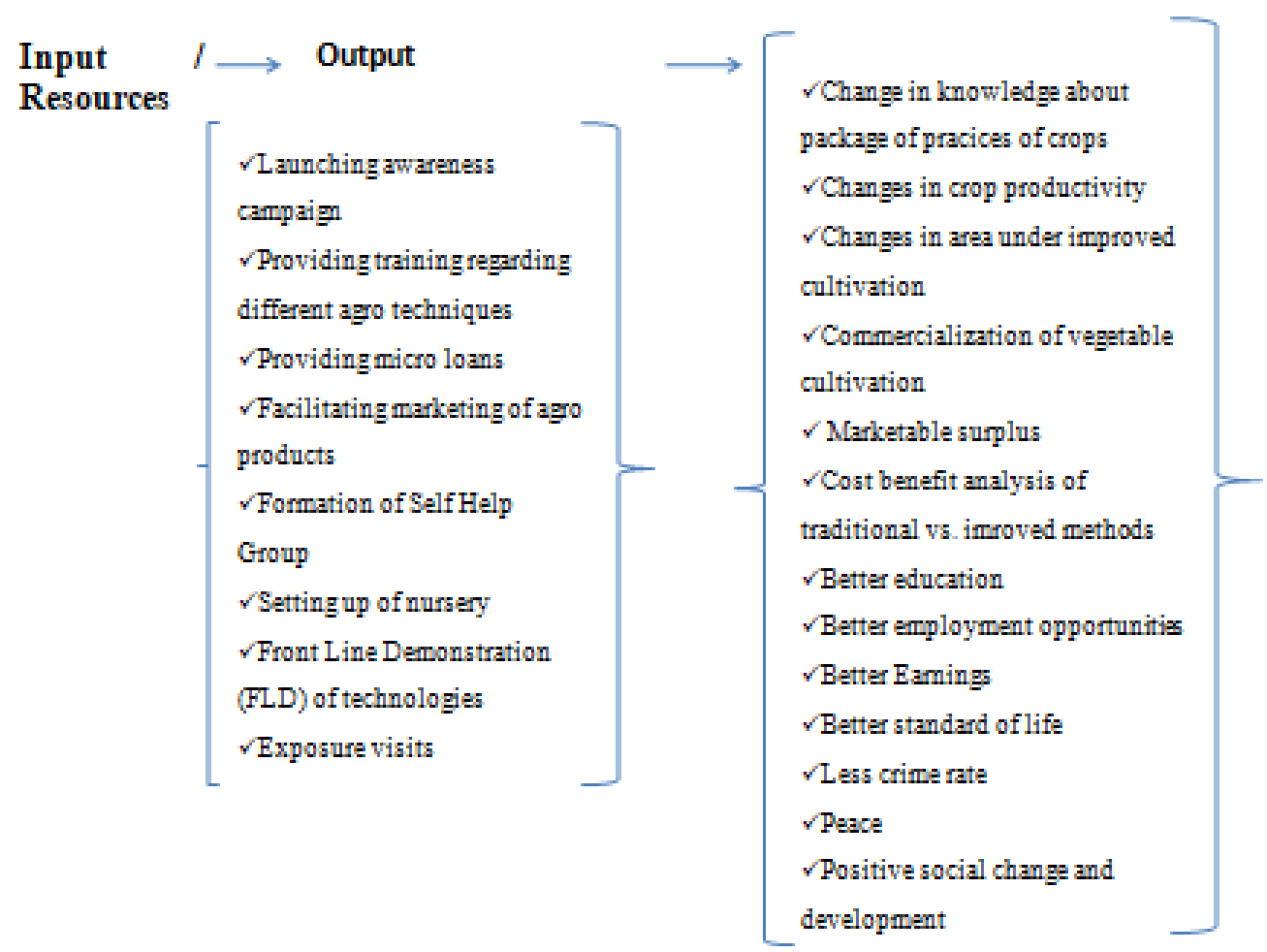




\section{Exposure visits}

The tribal farmers due to illiteracy and ignorance are highly unaware of advanced agricultural production technologies. Hence, the exposure visits were planned with an objective of exposing the tribal farmers to the new and improved practices of farming. This also gave them an opportunity to directly interact with progressive farming communities, research scientists and technology developers at various Agricultural Research Institutes, Universities, KVKs, Agro-industries, etc. thereby, upgrading their knowledge on various aspects of agriculture.

Four exposure visits were conducted at KVK, Tinsukia: KVK, Dibrugarh, AAU, Jorhat and CRS, AAU, Tinsukia during last 3 years and 197 tribal farmers were get benefitted by seeing various technologies developed at mentioned institutions and also obtained knowledge by the interaction with scientists on various issues related to modern agricultural practices and organic farming, Citrus Nursery, vermicomposting unit etc. (Table 4).

The overall impact of the project is illustrated in schematic diagram (Fig. 3).

In conclusion, during 2015-16, 2016-17 and 2017-18, the Tribal Sub Plan (TSP) project was implemented in tribal area of Tinsukia district of Assam. Several programmes like training, Farmer's day/ Agro-horti show, PRA exercises, FLD, exposure visits, were organised in order to develop awareness about advance agricultural practices for sustainable livelihood and occupational security. The training programmes were organized on IPM in Khasi mandarin, Assam lemon and ginger crops at 7 places and more than 650 tribal farmers were participated. During the study period, disorganised Assam lemon growers were organised into a Cooperative society in the name of "CRS-NAA Dihing Nemu Tengu Unnayan Samity" with Registration Number $26210304 / 1645$. Under the aegis of this Samity, the growers were made aware for collecting bargaining for selling of their produce to the middlemen, wholesalers and retailers. Resultant, the price realization increases manifolds and their income has become almost double. Assam lemon nurseries were also developed under the aegis of Samity at commercial level that provides planting material on regular basis to lemon growers of the areas. The associates of lemon society are earning good income and enjoying having sustainable livelihood. Some of the problems like drastically dropping of orange growers due to pest problems in orchards, exploitation of middlemen, and rhizome rot disease in ginger came in light through Participatory Rural Appraisal (PRA) exercises. Overcome these problems, some measures like, development of rejuvenation practices in orange orchards, organisation of Self-Help Groups (SHGs), dissemination of advance technologies of using bio-pesticides and bio-fungicides against rhizome rot and other diseases of ginger and development of methodology for planting and after care of ginger. These measures were enabling them to good harvest and obtaining good remuneration resultant improved their livelihood.

Thus, the implementation of TSP assured sustainable livelihood, occupational security and risk or hazards free health and environment to the tribal farmers by adopting advance agricultural practices.

\section{References}

1. Anonymous, Economic Survey of Assam, Directorate of Economics and Statistics, Assam Planning and development Department, Govt. of Assam, 2015. pp. 1-72. 
2. Paltasingh, T., and Paliwal, G., Tribal population in India: Regional dimensions and imperatives. Journal of Regional Development and Planning, 2014, 3(2): 27-36.

3. Girase, S., The problem of Indian tribal communities in current scenario. International Journal of Development Research, 2016, 6(5): 7924-7927.

4. Xaxa, V., Tribes and Development: Retrospect and Prospect; In: Social Exclusion and Adverse Inclusion: Development and Deprivation of Advasis in India, (eds Nathan, D. and Xaxa, V.), Oxford University press, New Delhi, 2012.

5. Deka, S., Nath, R.K., Sehgal, M., Barbora, A.C., Kakoti, R.K. and Ahuja, D.B., Socio-economic status of tribal farmers of Tinsukia of Assam: a case study. Int.J. Curr. Microbiol.App.Sci., 2017, 6(9): 2244-2248.

6. Deka, S., Sehgal, M., Kakoti, R.K. and Barbora, A.C., Module analysis for insect pest management of Khasi Madrin (Citrus reticulata Blanco) under climatic conditions of northeastern India. Journal of Entomology and Zoology studies, 2018, 6(4): 857861.

7. Dinakaran, D., Gajendran, G., Mohankumar, S., Karthikeyan, G., Thiruvudainambi, S., Jonathan, E. et al., Evaluation of integrated pest and disease management module for shallots in Tamil Nadu, India: a farmer's participatory approach. Journal of Integrated Pest Management. 2013, 4(2): 1-9.

\section{How to cite this article:}

Sikha Deka, Mukesh Sehgal, M. Idris and Barbora, A.C. 2019. Impact Assessment of Tribal Sub Plan (TSP) Project on Socio-economic Status of Tribal of Tinsukia District, Assam. Int.J.Curr.Microbiol.App.Sci. 8(04): 1670-1678. doi: https://doi.org/10.20546/ijcmas.2019.804.195 